\title{
AN ATTEMPT TO EXPLORE COMPONENTS OF EMPATHIC ARCHITECTURE IN HOSPITALS - A STUDY OF INDIAN HOSPITALS
}

\author{
Haimanti BANERJI \\ Department of Architecture and Regional Planning, \\ Indian Institute of Technology, \\ Kharagpur, PIN - 721302 \\ West Bengal, India \\ E-mail:haimanti@arp.iitkgp.ernet.in
}

Received 17 November 2014; accepted 17 September 2015

\begin{abstract}
Patients coming to the hospital are often fearful and confused and these feelings may impede recovery. Purpose of this study is to find out how the hospital stay can be made unthreatening, comfortable, and stress-free as possible by preserving, restoring and creating a preferred environment.

An exhaustive study has been conducted with a well designed questionnaire along with photography and behaviour mapping in three hospitals in Eastern India. A list of fourteen environmental attributes associated with creation of a healing environment within hospital set up was prepared. The perception of psychological comfort associated with these attributes was measured using a five point scale. For futher analysis, the researcher adopted Principal Component Analysis Technique and Varimax Factor Rotation Technique to extract major factors of hospital design with empathy. The findings of this research reassures the fact that no longer should the ethics of healthcare be viewed exclusively through the lens of physician-patient dyad but architects associated with hospital design bear equal responsibilities. The analyses have successfully highlighted issues like psycho - physical vulnerability of patients and family stress associated with hospitalization. The research concludes by suggesting some architectural design principles, which are helpful in generating a sense of trust, and faith on the hospital set up, familiarizing the patients and their relatives with hospital working system and process of treatment andcreating a non - clinical overall appearance. It also highlights the need for comforting the patients through various rejuvenating elements and helping them in negating the fear of unknown through information dissipation and counselling.
\end{abstract}

Keywords: empathy, therapeutic environment, healing architecture, stressor, psychological comfort, hospital design.

\section{Introduction}

Historically, it has been the role of architects, planners, and designers to interpret the needs, wishes, and capabilities of those who will use their buildings. Today, a need has been felt for advanced research to attain behavioral sophistication in facility design for proper determination of functional and ergonomic requirements and to translate them into the language of design and ultimately into bricks, mortar, and operating practices.

In India, a growing elderly population with increased affordability greatly emphasizes the need for better health care facilities in the country. Also the number of relatively younger but affluent people suffering from various types of lifestyle diseases is increasing. As a result health care providers in the country can is no longer limit themselves to providing curative and diagnostic services but they need to focus their attention towards overall wellbeing of people. It has been observed that due to lack of appropriate attention to components of environmental psychology, most of the high-tech super - specialty hospitals become harder for users to adapt to than the old buildings with poorer facilities. Often, these new hospitals are novel, but a bit confusing for the users, and this paper attempts to increase level of user satisfaction in such automated places. 


\section{Experience in hospital}

The mere thought of visiting any health care institution have been traditionally associated with negative feelings like tension, fear, nervousness, et - cetera. Through direct or vicarious experiences, most individuals learn to regard hospitals as unpleasant and frightening environments, associated with suffering and death (Brown 1961; Taylor 1979). Even in modern times, in - spite of progress made by health care professionals in providing more advanced and sophisticated medical facilities, many hospital visitors have negative feelings about the same, and their fears get compounded by a non therapeutic environment. The aim of this paper is to address this issue and identify environmental factors which can reduce users' stress.

Stress is any external demand, or threat, that seriously challenges the adaptive ability of an individual (Lazarus 1966; Lazarus, Launier 1978; Selye 1973). Selye (1973) noted that the exposure to a particular source of stress can deplete the physical and psychological resources of an individual. Also, stress can precipitate, relapse or create complications in people who are already ill (Andrews, Tennant 1978). Lazarus (1966) described six numbers of stressful stimuli he identified as 'noxious stimuli'. These noxious stimuli are (i) uncertainty about physical survival, (ii)maintenance of identity, (iii) loss of loved ones, (iv)inability to control immediate environment, (v)disruption of community life, (vi)avoidance of pain, or privation. Hospitalisation will cause all the above stressors to affect the patient. These may all occur at the same time, adding to irritation and stress (Schumaker, Reizenstein 1982). In addition to these, the structure of many departments also exposes the patients to unfamiliar noises, such as crying, moaning, groaning, shouting of other patients. Patients are often exposed to emergencies, unpleasant sights, and unpredictable behaviour from other users which aggravate the stressful situation.

If a person is frail, sick, tired or otherwise debilitated, there is less energy to expend on coping (Folkman et al. 1979). They show symptoms like disturbance of emotional balance, disruption of motor systems, physiological changes and disturbance of cognition.

\section{Therapeutic environment}

Stress factors in a general environment can have a negative effect on the immune system (Watson 1988). The concept of therapeutic environment is related to the branch of environmental psychology which deals with the psychosocial effects of environment, psychoimmunology, i.e. how environment affects the human immune system and neuroscience, i.e. how human brain perceives built environment. In many cases, the elaborate and complicated layout of ageneral hospital confuses people who are often fearful due to uncertainty of their health situation or their probable isolation from their friends and family. Stress can negatively affect a person's immune system and can suppress a person's emotional and spiritual power. This would have a retarding effect on the process of recovery and healing.

Lang (1971) concluded that in designing a building, there are three main functions to adhere to. The designer needs to ensure that:

- They maintain the physiological states necessary for people to attain their goals.

- They allow, or perhaps configure, specific patterns of behaviour required by people to attain their goals.

- They support, to some extent, the psychological states necessary for people to attain their goals, by fulfilling certain symbolic needs. If the environment produced is unresponsive to human needs and behaviour, the potential user will choose not to use it. If they have no choice but to use it, a stressful situation, either physiological or psychological, will result.

Environmental Psychology in general deals with study of mutual relations between the socio-physical environment at all scale and human behavior at all levels of analysis. Understanding the nature of this transaction requires extensive research to explore the degree of interdependence of physical environment systems and human systems (Moore 1987). With the help of knowledge in Environmental Psychology, one can design, manage, protect and/or restore environments that enhance reasonable behavior, predict what the likely outcome will be when these conditions are not met, and diagnose problem situations.

The built environment affects the attitude and behavior of people (Mazumdar 2000), through the processes of sensation, perception, and cognition. Along with the common environmental stressors (e.g., noise, climatic extremes) some define stress as the failure of preference. Cognitive stressors like prolonged uncertainty, lack of predictability and stimulus overload (De Young 1999) are included in the definition. Judith Heerwagen (2006) states that a person's sense of well-being influences productivity, creativity, and engagement. Researchers have focused on presence or absence of the following stimuli which help to create positive and productive places. 
Table 1. A summary of findings from earlier research in this field

\begin{tabular}{|c|c|c|}
\hline Stimuli & Researcher & Derivation / finding \\
\hline \multirow{2}{*}{$\begin{array}{l}\text { Crowding / unwanted } \\
\text { intrusion and lack of privacy } \\
\text { These are types of socio- } \\
\text { psychological stress due } \\
\text { to an increased density of } \\
\text { population } \\
\text { unwanted exposure to } \\
\text { people's view }\end{array}$} & Csermely (2000) & $\begin{array}{c}\text { Crowding causes complex changes at the behavioral and } \\
\text { physiological level }\end{array}$ \\
\hline & $\begin{array}{l}\text { Schumaker, Reizenstein } \\
\qquad \begin{array}{l}(1982) ; \\
\text { Proshansky et al. (1970) }\end{array}\end{array}$ & $\begin{array}{l}\text { Lack of privacy will affect the patients' expression of their } \\
\text { 'response to illness' } \\
\text { Pain may be accompanied by nausea and weakness, may } \\
\text { provoke responses such as altered facial expressions, } \\
\text { body movements, posture, vocalization or vomiting, } \\
\text { which sufferer would not wish to perform in public }\end{array}$ \\
\hline Misaffordance & Heft (1997) & $\begin{array}{l}\text { Users are unable to readily discern functional properties } \\
\text { of a space or incorrectly gauge building }\end{array}$ \\
\hline Disorientation & Evans, McCoy (1998) & $\begin{array}{c}\text { Human reactions are likely to encompass frustration, } \\
\text { annoyance, and, on occasion, even hostility or } \\
\text { helplessness }\end{array}$ \\
\hline Control & Cohen et al. 1986 & $\begin{array}{l}\text { Prolonged experiences with uncontrollable environment } \\
\text { lead to learned helplessness }\end{array}$ \\
\hline \multirow{4}{*}{$\begin{array}{l}\text { Restorative environment } \\
\text { Elements like retreat, } \\
\text { fascination, exposure to } \\
\text { nature provide resources that } \\
\text { can attenuate stress }\end{array}$} & $\begin{array}{l}\text { Kaplan, R. and Kaplan, S. } \\
\text { (1989) }\end{array}$ & $\begin{array}{l}\text { Involuntary attention or fascination facilitates recovery } \\
\text { from mental fatigue }\end{array}$ \\
\hline & Coss (1973) & $\begin{array}{c}\text { Fascination can be created by design elements such as } \\
\text { window views and various displays like aquarium, moving } \\
\text { water }\end{array}$ \\
\hline & $\begin{array}{l}\text { Hartig, Evans (1993); } \\
\text { Kaplan, R.\& Kaplan, S. (1989); } \\
\text { Ulrich (1992) }\end{array}$ & Natural elements and views of nature provide restoration \\
\hline & Whitehouse et al. (2001) & $\begin{array}{l}\text { Creation of therapeutic gardens or similar natural } \\
\text { environment is related to healing process }\end{array}$ \\
\hline \multirow{4}{*}{ Aesthetics } & $\begin{array}{l}\text { Ulrich (1991); } \\
\text { Hildebrand (1992); } \\
\text { Kuller, Lindsten (1992) }\end{array}$ & $\begin{array}{l}\text { Aesthetic and non - aesthetic surroundings create } \\
\text { an impression and affect a person consciously or } \\
\text { unconsciously }\end{array}$ \\
\hline & $\begin{array}{l}\text { Ulrich (2001); Ulrich( 1991); } \\
\text { Kuller, Mikellides (1993) }\end{array}$ & $\begin{array}{l}\text { Aesthetically pleasing surroundings improve a person's } \\
\text { affective condition and contribute to a feeling of well- } \\
\text { being }\end{array}$ \\
\hline & Mallay (2002); Eisen (2006) & Art therapy \\
\hline & $\begin{array}{l}\text { Stewart (2009); } \\
\text { Bonadies (2009); } \\
\text { Braun et al. (2009); } \\
\text { Briggs, Pehrsson (2008) }\end{array}$ & $\begin{array}{l}\text { Music therapy } \\
\text { Aroma therapy } \\
\text { Pet therapy } \\
\text { Bibliotherapy }\end{array}$ \\
\hline \multirow[t]{2}{*}{ Wayfinding } & $\begin{array}{l}\text { Evans, McCoy (1998); } \\
\text { Arthur, Passini (1992) }\end{array}$ & $\begin{array}{l}\text { 'Way finding' in hospitals is the first stressor the patient } \\
\text { can directly relate to the built environment. In addition, } \\
\text { the orientation of an interior space and the shape of the } \\
\text { setting directly influence the stimulation level. }\end{array}$ \\
\hline & Abu-Obeid (1998) & $\begin{array}{l}\text { Pictorial elements like shapes, surface qualities, special } \\
\text { qualities and entrances have a profound influence on } \\
\text { wayfinding }\end{array}$ \\
\hline
\end{tabular}

The above aspects have been successfully applied for designing a therapeutic environment for patients by reducing stress amongst them (Ulrich 1991). In addition to the above, an extensive review of the literatures in (Ghazali, Abbas 2011) supported the role of the physical environment towards the creation of the healing environment. While above-mentioned literatures have portrayed that the physical environment as a major determinant of a healing environment, there are others which have considered different components as impor- tant contributions. Apart from physical factors such as daylight, fresh air and quietness of the environment (Berg 2005) there are many non-physical factors that are of equal importance in contributing towards the creation of the healing environment Ghazali, Abbas (2011a). A more holistic approach was adopted in achieving such an environment more successfully in the proposed Optimal Healing Environment (OHE) framework (Ananth 2008). The OHE, described as "the social, psychological, physical, spiritual, and behavioral 
components of healthcare support and stimulate the body's innate capacity to heal itself" involved both the inner and outer environment comprising of seven components. The inner environment comprised of three components -developing healing intention, experiencing personal wholeness and cultivating healing relationship, while the outer environment comprised of the other four components - practicing healthy lifestyles, applying collaborative medicine, creating healing organization, and building healing spaces (Ghazali, Abbas 2011b).It can be summarised from literature review that hospital design needs empathy and empathy goes beyond compassion. It identifies with and attempts to understand what it would be like to be that bereaved person in this specific hospital environment. Attitudes of empathy allow the designer to experience vicariously the plight of caring survivors and others who attend the dying scene.

The present study was intiated with an idea to make hospital stay as unthreatening, comfortable, and stressfree as possible by preserving, restoring and creating a preferred environment. The main aim of the researcher has been to ensure optimal care to individual patients and assurance of proper care and treatment to their families in a warm, friendly and affirming environment. The objective is to provide spaces that simultaneously address the varied needs of individual patients, their families and a diverse team of health care professionals and volunteers.

The paper seeks to identify the components of a therapeutic environment that would present a conducive setup for rendering optimum level of curative and palliative care within hospitals in Urban Indian context.

\section{Methods}

The term empathy is primarily borrowed from sociology where it refers to an association with another person. In the field of architecture, empathy means a positive association of the users with the built environment i.e. congruence between environmental components and user's expectations.

The ethics of designing a healing environment focuses on the designer's responsibility to maintain connection between users and environment. It includes as its distinctive elements the following three: (a) attention to particularothers in actual contexts, (b) focus on needs versus interests of thoseparticular others, and (c) a commitment to dialogue as a primary means of moral deliberation.

The vision of the present study is compassionate design and the aim has been to develop a set of parameters for achieving a psycho - physically stimulating environment in Indian hospitals. Such formulation of parameters, preliminary require identification and rating of environmental components by the respondents based on expected benefit from them. An exhaustive list of fourteen environmental attributes associated with creation of a healing environment within hospital set up was prepared. While selecting these parameters, the author has relied upon theoretical findings from previous research works, and opinions from experts.

The present research has incorporated prolonged studies in three hospitals in eastern India in order to understand user's needs and priorities. These hospitals were selected based on certain criteria like scale, location, layout, availability of facilities and type of patients to avoid any bias arising out of these factors.

Table 2. Environmental attributes associated with psychological comfort

\begin{tabular}{lr}
\hline No & Attributes \\
\hline 1 & Adequacy of natural light and ventilation \\
\hline 2 & Scope to view support nurses / staff giving an assurance of help being available should the need rise \\
\hline 3 & Neat \& organized appearance indicating clinical perfection and mechanical efficiency \\
\hline 4 & Use of colour / furniture and interior décor which are not typical of a hospital \\
\hline 5 & Clear architectural layout ensuring visual connectivity between different places - presence of landmark, zones of interest \\
\hline 6 & Belongingness and association to environment \\
\hline 7 & Clear instruction regarding step wise actions \\
\hline 9 & Clear signage and / other wayfinding measures \\
\hline 10 & Use of cleaning chemicals / room fresheners which are generally for domestic use \\
\hline 11 & Adequacy of information being displayed about various ailments and treatment procedure \\
\hline 12 & Scope of counselling by well trained psychologist and medical personnel for patient and patient parties \\
\hline 13 & Ensuring patients are not vulnerable to accidents or pain while being taken from one place to another or during \\
\hline 14 & any treatment / diagnosis / stay \\
\hline
\end{tabular}


To ensure normality of the sample population and avoid any skewness in the data, fair representation of hospitals differing in the above aspects is allowed. In the survey conducted, the respondents were asked to rate each attribute based on the expected reduction of physical and psychological stress.

According to Henry et al. (1984), the minimum number of samples $(n)$ for factor analysis with $(y)$ number of variables should be more than $30+(y+$ 3 )/ 2 . For this study about 200 patients were interviewed. The sampling adequacy has been measured by the Kaiser - Mayer - Olkin (KMO) test which has been found satisfactory with value of 0.73 (i.e. greater than $0.5)$. The perception of psychological comfort associated with these attributes was measured using a five point scale, (1) measures the lowest perception and (5) implies highest. While conducting these interviews, the author has largely relied on the phenomenological experience of empathy which is the natural ability of the respondents to understand the emotions and feelings of others, whether one actually witnessed his or her situation, perceived it from a photograph, read about it in fiction book, or merely imagined it (Jean, Jackson 2004). It was observed that although all these fourteen attributes are responsible for creating a healing environment, there is scope for further categorising them under some broader heads for generic purpose based on certain commonalities. Factor Analysis is used to find latent variables or factors by reformulating a set of observed variables.Data cleaning and missing data analysis is the first step for initiating any analysis process and the same was done using SPSS software before performing Factor analysis. The data set was also analyzed for skewness.

\section{Results and discussions}

SPSS software has been used to prepare the correlation matrix and extract the relevant factors F1, F2, F3, F4 (refer Table 4). Principal Component Analysis Technique and Varimax Factor Rotation Technique have been adopted here for improved interpretability. The following table shows loadings of fourteen varia-

Table 3. Correlation Coefficient for the average values of effectiveness of the environmental attributes in ensuring psychological comfort

\begin{tabular}{|c|c|c|c|c|c|c|c|c|c|c|c|c|c|c|}
\hline 息 & 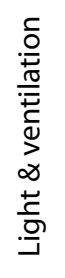 & 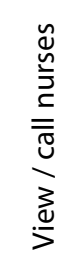 & 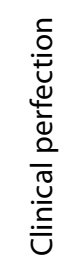 & 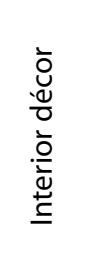 & 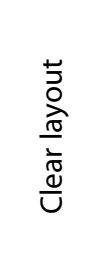 & 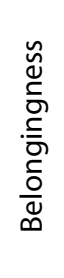 & 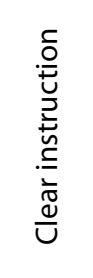 & 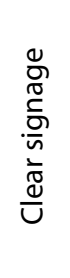 & 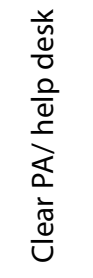 & 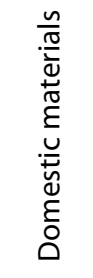 & 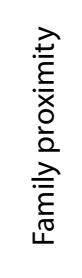 & 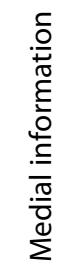 & 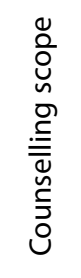 & $\begin{array}{l}\frac{0}{0} \\
\frac{0}{0} \\
\frac{0}{0} \\
\frac{1}{5} \\
3 \\
\frac{1}{2}\end{array}$ \\
\hline $\begin{array}{l}\text { Light and } \\
\text { ventilation }\end{array}$ & 1.0 & 0.06 & -.12 & $.33^{*}$ & -.12 & .08 & -.02 & .04 & .01 & .21 & -.03 & .28 & $.35^{*}$ & .04 \\
\hline $\begin{array}{c}\text { View / call } \\
\text { nurses }\end{array}$ & & 1.0 & 0.0 & .16 & $.35^{*}$ & .23 & .12 & .12 & .08 & .05 & .31 & -.09 & .23 & .20 \\
\hline $\begin{array}{l}\text { Clinical } \\
\text { perfection }\end{array}$ & & & 1.0 & $\begin{array}{l}-.34 \\
*\end{array}$ & $.51 * *$ & .11 & $.13^{* *}$ & $\begin{array}{l}.47 \\
* *\end{array}$ & $.39 *$ & $-.39 *$ & .11 & .27 & -.05 & .28 \\
\hline Interior décor & & & & 1.0 & -.07 & .11 & -.03 & .18 & .25 & $.72^{* *}$ & .12 & 0.0 & .11 & -.02 \\
\hline Clear layout & & & & & 1.0 & .17 & .24 & $\begin{array}{l}.55 \\
* *\end{array}$ & $.37^{*}$ & -.18 & .10 & -.08 & -.13 & -.18 \\
\hline Belongingness & & & & & & 1.0 & $.42 * *$ & .19 & .31 & .25 & .15 & -.08 & -.13 & .18 \\
\hline Clear instruction & & & & & & & 1.0 & $\begin{array}{l}.5 \\
* *\end{array}$ & $.42^{* *}$ & -.05 & $\begin{array}{l}.49 \\
* *\end{array}$ & .29 & -.13 & .29 \\
\hline Clear signage & & & & & & & & 1.0 & $.65^{* *}$ & -.01 & .31 & $.35^{*}$ & .22 & .30 \\
\hline $\begin{array}{c}\text { Clear PA/ help } \\
\text { desk }\end{array}$ & & & & & & & & & 1.0 & .08 & .18 & .04 & -.01 & .11 \\
\hline $\begin{array}{l}\text { Domestic } \\
\text { materials }\end{array}$ & & & & & & & & & & 1.0 & -.01 & 0.0 & .19 & -.17 \\
\hline Family proximity & & & & & & & & & & & 1.0 & .11 & -.21 & .39 \\
\hline Medial info & & & & & & & & & & & & 1.0 & .52 & .17 \\
\hline Counselling & & & & & & & & & & & & & 1.0 & -.09 \\
\hline Not vulnerable & & & & & & & & & & & & & & 1.0 \\
\hline & & & $\begin{array}{r}\text { Note } \\
* *\end{array}$ & 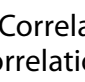 & $n$ is & nific & $\begin{array}{l}\text { tat } \\
\text { t } 0.0\end{array}$ & 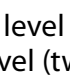 & $\begin{array}{l}0- \\
- \text { tai }\end{array}$ & & & & & \\
\hline
\end{tabular}


Table 4. Varimax rotation of principal factor solutions

\begin{tabular}{|c|c|c|c|c|c|}
\hline Attributes & $\mathrm{FI}$ & F II & F III & F IV & $\begin{array}{l}\text { Comm- } \\
\text { unality }\end{array}$ \\
\hline Adequacy of natural light and ventilation & -.084 & .414 & .085 & .540 & .447 \\
\hline $\begin{array}{l}\text { Can view the support nurses / staff and an assurance } \\
\text { of help being available should the need rise }\end{array}$ & -.078 & .226 & .694 & -.203 & .580 \\
\hline $\begin{array}{l}\text { Neat \& organized appearance indicating clinical } \\
\text { perfection and mechanical efficiency }\end{array}$ & .637 & -.515 & .121 & .108 & .698 \\
\hline $\begin{array}{c}\text { Use of colour / furniture and interior décor which are } \\
\text { not typical of a hospital }\end{array}$ & .071 & .845 & .104 & .127 & .746 \\
\hline $\begin{array}{c}\text { Clear architectural layout ensuring visual connectivity } \\
\text { of different places - presence of landmark, zones of } \\
\text { interest }\end{array}$ & .761 & -.212 & -.334 & .049 & .738 \\
\hline Belongingness and association to environment & .498 & .404 & .070 & -.035 & .539 \\
\hline Clear instruction regarding step wise actions & .637 & -.048 & .482 & .014 & .640 \\
\hline Clear signage & .792 & .031 & .223 & .309 & .774 \\
\hline $\begin{array}{c}\text { Distinct system of announcement and availability of } \\
\text { patient help desk }\end{array}$ & .766 & .162 & .107 & -.032 & .625 \\
\hline $\begin{array}{l}\text { Use of cleaning chemicals / room fresheners which are } \\
\text { domestic use }\end{array}$ & -.042 & .859 & -.059 & .073 & .748 \\
\hline Proximity to family members & .274 & .048 & .687 & -.055 & .553 \\
\hline $\begin{array}{l}\text { Adequacy of information being displayed about } \\
\text { various ailments and treatment procedure }\end{array}$ & .195 & -.092 & .126 & .803 & .708 \\
\hline $\begin{array}{l}\text { Counseling scope by well trained psychologist and } \\
\text { medical personnel for patient as well as patient parties }\end{array}$ & .039 & .164 & -.325 & .789 & .756 \\
\hline $\begin{array}{c}\text { Not being vulnerable to accidents or pain while } \\
\text { being taken from one place to another or during any } \\
\text { treatment / diagnosis / stay }\end{array}$ & .056 & -.280 & .682 & .2784 & .627 \\
\hline Cumulative variance explained in \% & 23.98 & 40.62 & 54.74 & 65.78 & \\
\hline
\end{tabular}

bles on four factors extracted. Adopting Kaiser's criterion rule, those factors with Eigen value of one or more is retained and the cumulative variance is calculated. The four factors which are extracted account for more than $65 \%$ of the total variance explained. A higher factor loading implies a domination of the corresponding variable.

On the basis of the various factor loading obtained, following interpretations are made.

1. Factor I, which accounts for $23.98 \%$ of the varianceis associated with having a neat $\&$ organized appearance - presence of landmark, zones of interest (0.637), clear architectural layout ensuring visual connectivity of different places (0.761), clear instruction regarding step wise actions to be performed (0.637) clear signage (0.792) and distinct system of announcement and availability of patient help desk (0.766). All these attributes instill a sense of psycho - physical comfort and an urge to move in a clear and comprehensible environment. The factor has therefore been named as "Clarityon the procedural matters, sequ- ence of activities and movement pattern within Hospital"Factor.

2. Factor II, which accounts for $40.62 \%$ of the varianceis positively related to the use of colour / furniture and interior décor which are not typical of a hospital (0.845), use of cleaning chemicals / room fresheners which are domestic use (0.859), neat \& organized appearance - institutional perfection and mechanical efficiency has got a negative loading $(-0.515)$ since this creates an impression of mechanical and less humanized attitude in the sub - conscious minds of the patients. This factor is termed as "Preference for a Non - clinical appearance" factor.

3. Factor III, which accounts for $54.74 \%$ of the varianceincludes the need for viewing the support nurses / staff and an assurance of help being available should the need arise (.694), proximity to family members (0.687) and not being vulnerable to accidents or pain while being taken from one place to another or during any treatment / diagnosis / stay (0.682). These attributes reveal 
preference of respondents to be within a comfort zone where there is a sense of safety and security. This is termed as "Sense of being looked after" factor.

4. Factor IV, which accounts for $65.78 \%$ of the variancecontains aspects of adequacy of information being displayed about various ailments and treatment procedure (0.803) and scope for counseling by well trained psychologist and medical personnel for patient as well as patient parties (0.789). These together may be termed as "Negating fear of the unknown" factor.

The results of this Factor Analysis, if heuristically interpreted, four major factors namely: (1) ensuring clarity and comprehensibility (2) creating a non - clinical appearance (3) providing care and protection (4) negating the fear of unknown appear to be largely responsible for ensuring psychological comfort for different categories of patients in similar situations.

The findings of this research implies that no longer should the ethics of healthcare be viewed exclusively through the lens of physician-patient dyad but architects associated with hospital design bear equal responsibilities. It was established by earlier researchers that architecture, which heals, requires a milieu that allows harmony - with nature and components of healing architecture include adequate daylight, sound of water and aroma along with other elements of visual aesthetics like colour, nature, and artwork. However, the current findings highlight issues like psycho - physical vulnerability of patients and family stress associated with hospitalization. It focuses on the non-medical needs of family members and visitors as an important factor in deciding the merits of specific designs and policies for hospital architecture.

\section{Conclusions}

The research concludes by highlighting importance of factors which are closely linked with generating a sense of trust and faith on the hospital set up, familiarizing the patients and their relatives with hospital working system and process of treatment. It also highlights the need for comforting them through various rejuvenating elements, helping in negating the fear of the unknown through information dissipation and counselling. The focus is towards creating a non - clinical overall appearance. It suggests that the following strategies be incorporated at the design and operation level.

- To include some special features or places in hospital where patients can be reassured, families consoled, and the power of medical diagnosis and prognosis be made less overwhelming and frightening. This can be through rejuvenating elements like view of nature, daylight, open air café, book - shop, gift shop and similar elements which are traditionally known as effective mind - diverters.

- To include relevant posters / boards which would create awareness about various diseases andalso speak positively about treatment procedures and raise hope of recovery.

- To include prayer rooms or meditation rooms which will provide a tranquil space for quieting patients and family members as they pray for comfort, strength, guidance or whatever they would need to accept the present state of affairs they are going through.

- To ensure that a patient's first impression of a hospital is not that of a non-home-like environment which elicits feelings of dread, fear, and revulsion. This can be achieved by use of everyday elements like intimate seating areas in clusters instead of rows of seating in waiting areas, upholstery which creates a homely atmosphere, paintings, wall cloc$\mathrm{ks}$, indoor plants, magazine rack et - cetera. The strong smell of antiseptic or analgesic lotions, cleaning chemicals should be avoided which has a traditional association with hospitals.

- To provide access to medical literature for patients to assess and understand their ailment and heath status, treatment options and time for recovery.

- To comfort patient by creating a set up which, assures desired privacy and control over immediate space. Private rooms or double rooms are preferred to dormitories. In the third case, private bays should be provided, giving scope for interaction or seclusion at will.

- To ensure proper control of patients over immediate environment. Scope to control radio, television, reading light, night light and freedom to choose artwork and daily menu are quite effective. Providing personal storage area for patient belongings, giving access to mini library and computer terminals are some useful measures in creating a sense of territoriality and belongingness and at the same time avoiding the feeling of disassociation from the everyday world while staying in hospital. - To provide family zone in patient room to accommodate one member at least.

- To provide places where patients can engage socially with family and other patients without any physical discomfort or compromise of the clinical norms. This can be in form of pantry where family members can prepare food for patients and can eat together.

- To allow access to mobile phones, Internet and Skype except for during the compulsory quite hours as per hospital rules. 

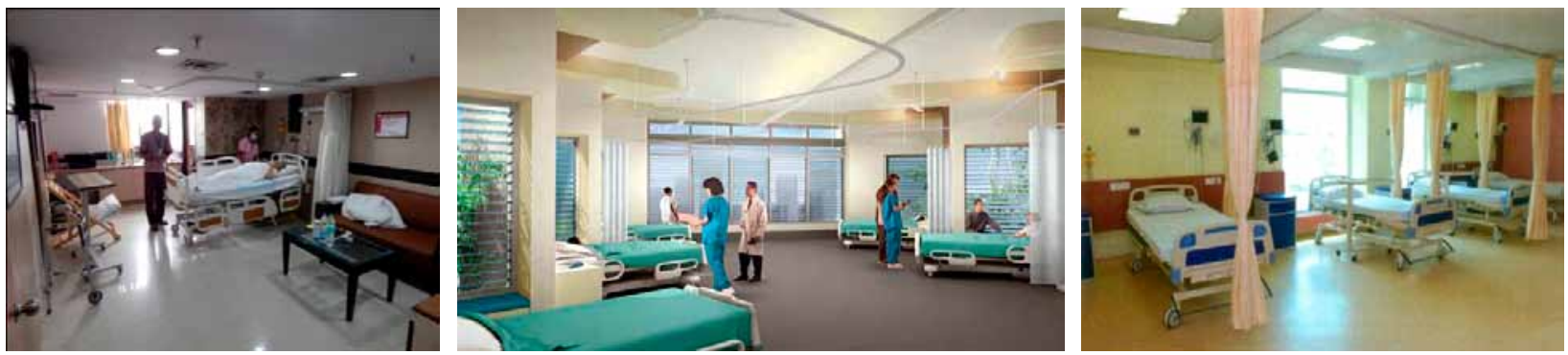

Patient's rooms with view of the window

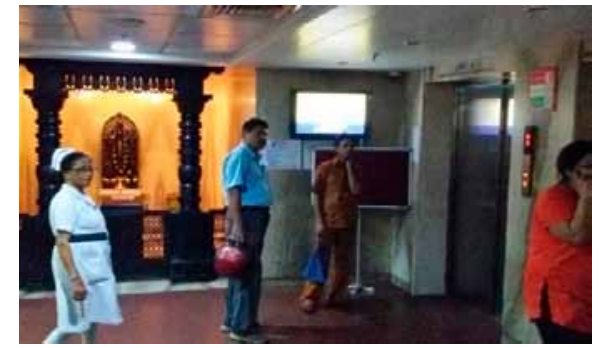

Praying enclave

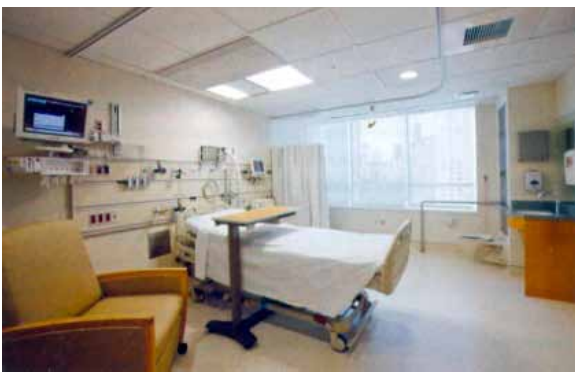

ICU

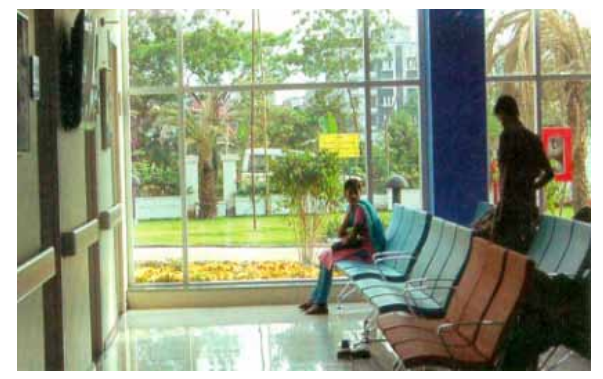

Waiting lobby with adequate sunlight, innovative furniture and bright colours
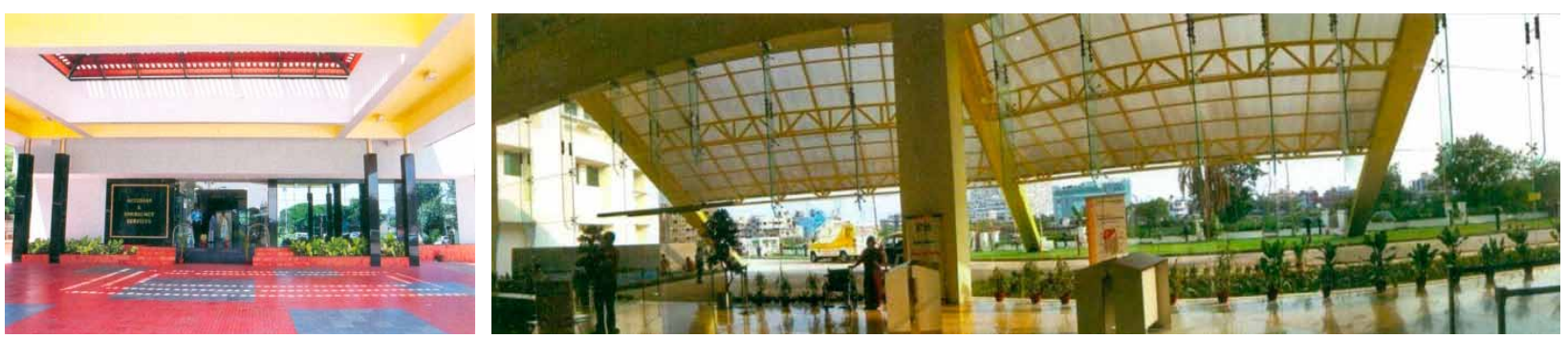

Inviting entry lobby and porch to hospital
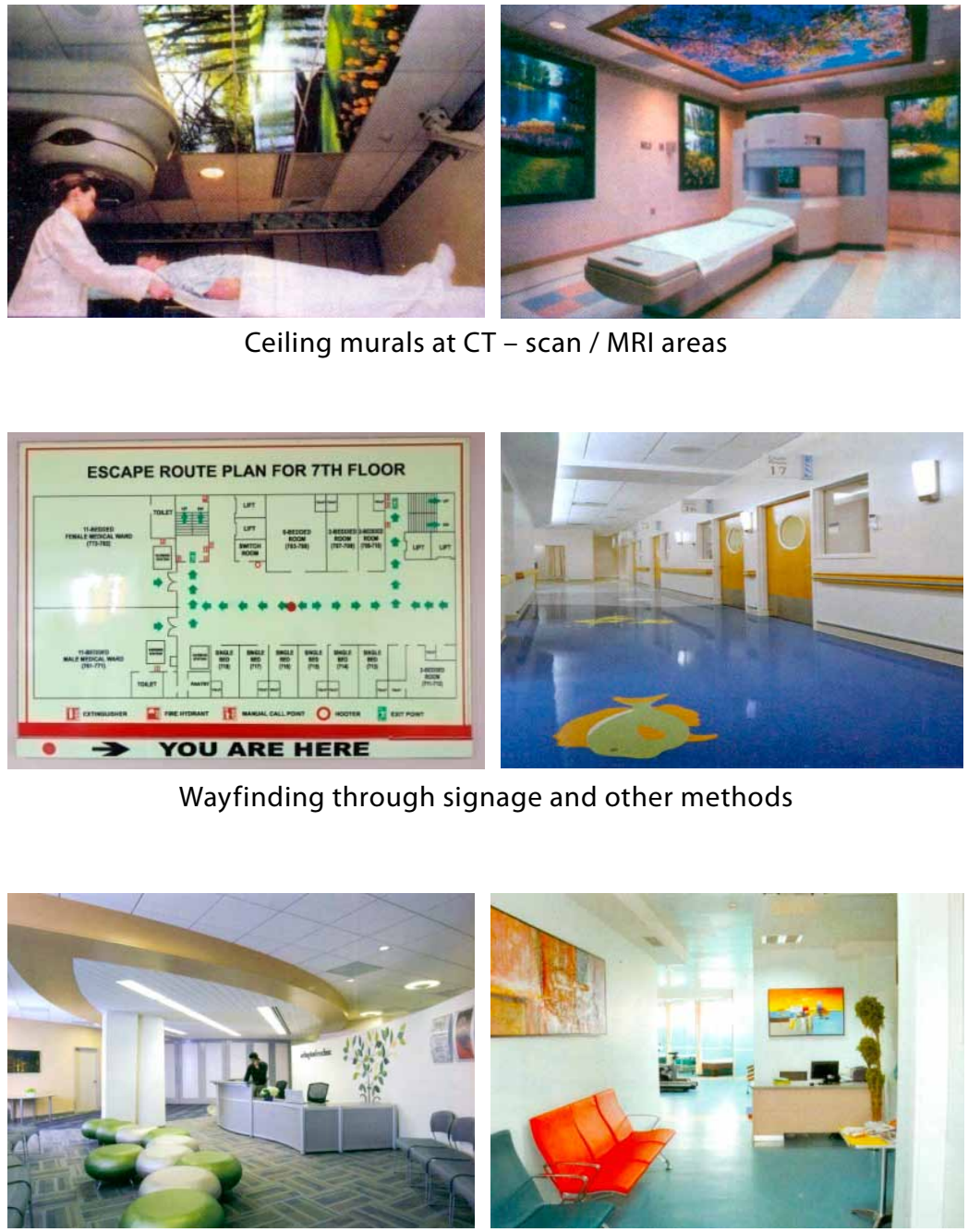

Ceiling murals at CT - scan / MRI areas
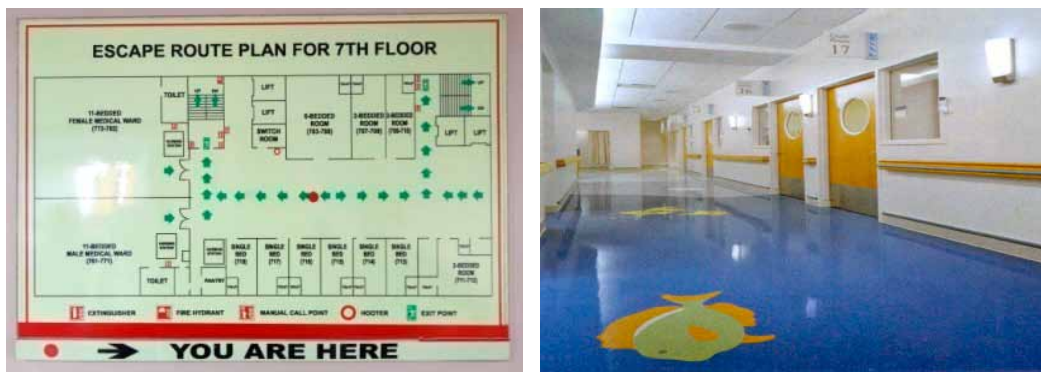

Wayfinding through signage and other methods

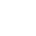




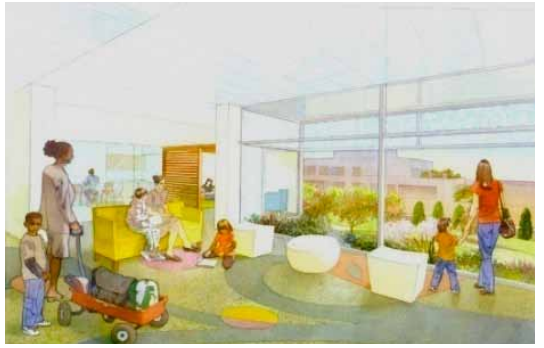

Family niche

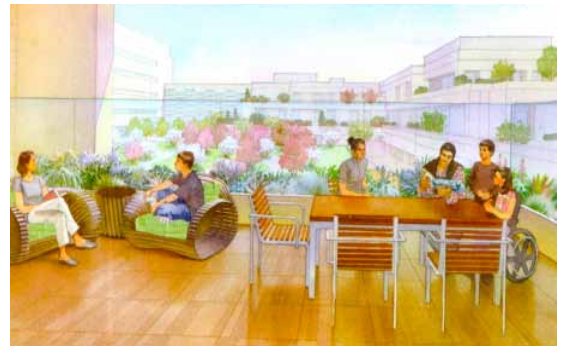

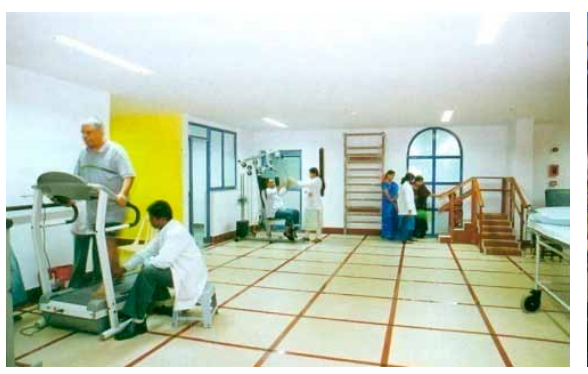
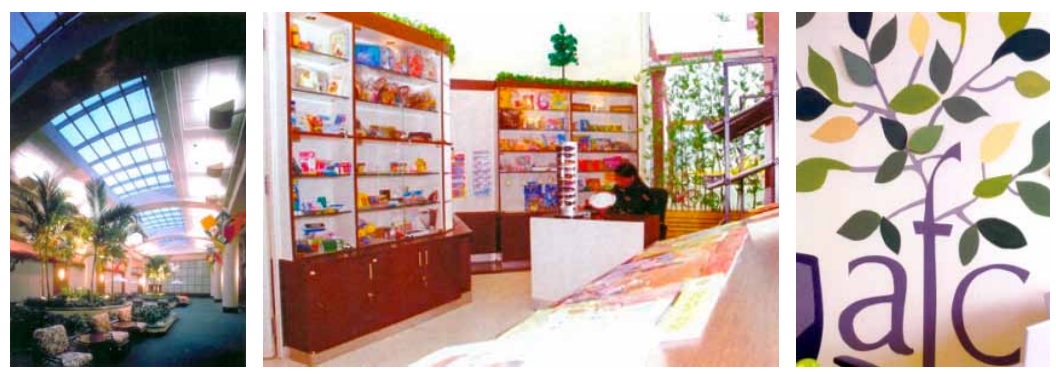

Rejuvenating elements like plants, gift shop, interesting mural

Above are some examples of existing hospital buildings that meet the above requirements.

Apart from these, the analyst however acknowledges existence of other relevant factors and architectural solutions, which may be identified through future research in this field. Future research may also focus upon inclusion into therapeutic environment those components which would prove to be beneficial for staff and caregivers in terms of satisfaction, less work related fatigue, effectiveness, and staff retention.

\section{Funding}

This work was supported by Sponsored Research and Industrial Consultancy Cell, Indian Institute of Technology, Kharagpur, West Bengal, India.

\section{References}

Abu-Obeid, N. 1998. Abstract and scenographic imagery: The effects of environmental form on wayfinding, Journal of Environmental Psychology 18(2): 159-173.

http://dx.doi.org/10.1006/jevp.1998.0082

Ananth, S. 2008. Healing environments: the next natural step, Explore 4(4): 273-274. http://dx.doi.org/10.1016/j.explore.2008.04.010

Andrews, G.; Tennant, C. 1978. Being upset and becoming ill: an appraisal of the relations between life events and physical illness, Medical Journal of Australia 1(6): 324-327

Arthur, P.; Passini, R. 1992. Wayfinding: people, sign and architecture. New York: McGraw-Hill

Berg, A. V. D. 2005. Health impacts of healing environments - A review of evidence for benefits of nature, daylight, fresh air and quiet in healthcare settings. Groningen: University Hospital Groningen.
Bonadies, V. 2009. Guided imagery as a therapeutic recreation modality to reduce pain and anxiety, Therapeutic Recreation Journal 43(2): 43-55.

Braun, C.; Stangler, T.; Narveson, J.; Pettingell, S. 2009. Animalassisted therapy as a pain relief intervention for children, Complementary Therapies in Clinical Practice 15(2): 105-109. http://dx.doi.org/10.1016/j.ctcp.2009.02.008

Briggs, C. A.; Pehrsson, D. E. 2008. Use of bibliotherapy in the treatment of grief and loss: a guide to current counseling practices, Adultspan Journal 7(1): 32-42.

http://dx.doi.org/10.1002/j.2161-0029.2008.tb00041.x

Brown, E. L. 1961. Newer dimensions of patient care. Use of physical and social environment of general hospital for therapeutic purposes. New York: Rusell Sage Foundation.

Cohen, S., et al. 1986. Behavior health and environmental stress. New York: Plenum. ISBN 978-0-306-42138-9

Coss, R. C. 1973. The cut-off hypothesis: its relevance to the design of public places, Man-Environment Systems 3: 417-440.

Csermely, P. 2000. Crowding stress, in G. Fink (Ed.). Encyclopaedia of stress. San Diego, CA: Academic Press.

De Young, R. 1999. Environmental psychology, in D. E. Alexander, R. W. Fairbridge (Eds.). Encyclopedia of Environmental Science. Hingham: Kleewer Academic Publishers.

Eisen, S. L. 2006. The healing effects of art in pediatric healthcare: art preferences of healthy children and hospitalized children: Doctoral dissertation. Texas A \& M University, USA.

Evans, G. W.; Mc Coy, J. M. 1998. When buildings don't work: the role of architecture in human health, Journal of Environmental Psychology 18(1): 85-94.

http://dx.doi.org/10.1006/jevp.1998.0089

Folkman, S.; Schaefer, C.; Lazarus, R. 1979. Cognitive processes as mediators of stress \& coping, in V. Hamilton, D. M. Warburtons (Eds.). Human stress \& cognition: information processing approach. London: Wiley.

Ghazali, R.; Abbas, M. Y. 2011a. Paediatric wards: healing environment assessment, Asian Journal of Environment-Behaviour Studies (ajEBs) 2(4): 63-76. 
Ghazali, R.; Abbas, M. Y. 2011b. Physical environment: the major determinant towards the creation of a healing environment?, Procedia - Social and Behavioral Sciences 30: 1951-1958. http://dx.doi.org/10.1016/j.sbspro.2011.10.379

Hartig, T.; Evans, G. W. 1993. Psychological foundations of nature experience, in T. Garling, R. Golledge (Eds.). Behavior and environment: geographic and psychological approaches. Amsterdam: Elsevier, 427-457.

Heerwagen, J. 2006. The psychological value of space [online], [cited 23 May 2008]. Available from Internet: http://www. wbdg.org/design/psychspace_value.php

Heft, H. 1997. The relevance of Gibson's ecological approach to perception for environment-behavior studies, in G. T. Moore, R. W. Marans (Eds.). Advances in Environment, Behavior, and Design. Vol. 4. New York: Plenum, 72-108.

Henry, R. C.; Lewis, C. W.; Hopke, P. K.; Williamson, H. J. 1984. Review of receptor modelling fundamentals, Atmospheric Environment 18(8): 1507-1515. http://dx.doi.org/10.1016/0004-6981(84)90375-5

Hildebrand, G. 1999. Origin of architectural pleasure. California: California Press.

Jean, D.; Jackson, P. 2004. The functional architecture of human empathy, Behavioral and Cognitive Neuroscience Reviews 3(2): 71-100. http://dx.doi.org/10.1177/1534582304267187

Kaplan, R.; Kaplan S. 1989. The experience of nature. Cambridge: Cambridge Press.

Kuller, R.; Lindsten, C. 1992. Health and behavior of children in classrooms with and without windows, Journal of Environmental Psychology 12(4): 305-317. http://dx.doi.org/10.1016/S0272-4944(05)80079-9

Kuller, R.; Mikellides, B. 1993. Simulated studies of color, arousal, and comfort. Environmental Simulation. Research and Policy Issues. New York: Plenum Press, 163-190.

Lang, J. 1971. Architecture for human behaviour, Franklin Institute, Philadelphia, in Ch. Burnette, J. Lang, D. Vaschon(Eds.). Collected Papers for Mini-Conference, 11 November 1971. Philadelphia Chapter, American Institute of Architects, USA.

Lazarus, R. 1966. Psychological stress \& the coping process. New York: McGraw Hill.

Lazarus, R.; Launier, R. 1978. Stress related transactions between person and the environment, in L. A. Pervin, M. Lewis (Eds.). Perspective in interactional psychology. New York: Plenum press. http://dx.doi.org/10.1007/978-1-4613-3997-7_12

Proshansky, H. M.; Felson, W. H.; Rivlin, L. G. 1970. Environmental psychology. New York: Holt Renehart \& Winston.

Mallay, J. M. 2002. Art therapy, an effective outreach intervention with traumatized children with suspected acquired brain injury, Arts in Psychotherapy 29(3):159-172. http://dx.doi.org/10.1016/S0197-4556(02)00147-8
Mazumdar, S. 2000. Design professionals and the built environment, in P. Knox, P. Ozolins, (Eds.). People and the built environment. Chichester: Wiley, 157-169.

Moore, G. T. 1987. The physical environment and cognitive development in child-care centers, in C. S. Weinstein, T. G. David (Eds.). Spaces for children: The built environment and child development. New York: Plenum Press, 41-72. http://dx.doi.org/10.1007/978-1-4684-5227-3_3

Schumaker, S. A.; Reizenstein, J. E. 1982. Environmental factors aflecting inpatient stress, in Acute Care Hospitals. Environmental Stress. Cambridge: Cambridge University Press.

Selye, J. H. 1973. The evolution of stress concept, Landscape and Urban Planning 73(2-3): 167-183.

Stewart, K. 2009. Patterns - a model for evaluating trauma in NICU, Music Therapy, Music and Medicine 1(1): 29-40. http://dx.doi.org/10.1177/1943862109338370

Taylor, S. R. 1979. Hospital patient behaviour: reactance, helplessness, or control, Journal of Social Issues 35(1): 156-184. http://dx.doi.org/10.1111/j.1540-4560.1979.tb00793.x

Ulrich, R. 1984. View through a window may influence recovery from surgery, Science 224(4647): 420-421. http://dx.doi.org/10.1126/science.6143402

Ulrich, R. 1991. Effects of interior design on wellness: theory on recent scientific research, Journal of Health Care and Interior Design 3: 97-109.

Ulrich, R. S. 1992. How design impact wellness, Health Care Forum Journal 35: 20-25.

Ulrich, R. 2001. Effects of healthcare environmental design on medical outcomes, in A. Dilani (Ed.). Art, Design \& Health. Stockholm: Svensk Byggtjänst.

Watson, J. 1988. Caring. Boston: Little, Brown and Company.

Whitehouse, S.; Varni, J. W.; Seid, M.; Cooper-Marcus, C.; Ensberg, M. J.; Jacobs, J. R., et al. 2001. Evaluating a Children's Hospital garden environment: utilization and consumer satisfaction, Journal of Environmental Psychology 21(3): 301-314. http://dx.doi.org/10.1006/jevp.2001.0224

\section{HAIMANTI BANERJI}

Dr., (Ph.D 2008, MCP 2004, B. Arch 2002), is currently working as Assistant Professor in the Department of Architecture and Regional Planning, Indian Institute of Technology, Kharagpur. Dr. Banerji had completed her graduation in Architecture from Bengal Engineering College, Shibpur, West Bengal, India in 2002 and subsequently obtained her Master degree in City Planning and PhD from IIT Kharagpur, West Bengal, India in 2004 and 2007 respectively.

Her research interests include Universal Design, Behavioral Architecture, Housing and Habitat, Ergonomics and Product Design, Medicare Planning, Settlement System Planning and Urban Design. Haimanti is a Co-author of Universal Design India Principles (UDIP). Dr. Banerji believes in interactive learning and takes active role in spearheading more of international collaboration to break boundaries between institutes. 